\title{
Analysis Of The Effects Of Ethnicity On Political Marketing In Ghana
}

Joshua Alabi, (E-mail: ipsdp05@yahoo.com), Institute of Professional Studies Legon, Accra, Ghana

Goski Alabi, Institute of Professional Studies Legon, Accra, Ghana

\begin{abstract}
Analysis of vote data suggests that, among other performance factors, ethnicity plays a major role in the acceptability of political marketing approaches of partisan politics in Ghana. This features quite prominently in the ethnic based voting pattern that has prevailed over the years and the communal voting pattern that is emerging in Ghana as a result of increasing urbanization. The analysis makes it evident that political parties with very strong ethnic support bases are those that have stood the test of time no matter what marketing tools or approaches are employed, though political marketing gains to a large extent depend on the features of the political product, the political product benefit and the political marketing support services. The paper compares the results of the four different elections of the Fourth Republic of Ghana and attempts to make inferences on the effects of ethnicity on the voting patterns of the four (4) Presidential elections in the Fourth Republic. The analysis uses the voting patterns as a pointer to the acceptability and effectiveness of a political party's marketing approach and by deduction, analyzes which political marketing variables contribute to the acceptability of political parties. It also attempts to generate understanding of the political marketing variables such as dimensions of the Political Market, the Political Product and the 'Political Product Support Services' and compares effects of these variables with effects of ethnicity on political marketing outcomes in Ghana. The paper specifically compares features of the political product which include Party Philosophy, Perceived Party Identity, Manifesto, Political Party Leadership, Previous Performance, Particularistic Benefits, Party Paraphernalia on elections outcomes among identified or classified ethnic groups at regional or communal level. In addition, the analysis reveals that personality, perceived party image or identity of the political party and communication are salient in determining political marketing outcomes or fortunes of a political party and to a less extent political product benefits based on past performance and experiences, whereas effects of particularistic benefits and party paraphernalia or the political marketing support services are less prominent.
\end{abstract}

\section{INTRODUCTION}

\section{Background}

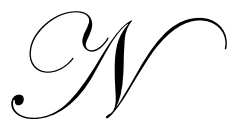

umerous authors have debated the role of ethnicity in determining election fortunes of a political party in electoral and democratic politics in Africa and often the case of Ghana has been cited (Krutz 2005, Chazan 1982, Rothchild 1978, Ayee 2005, Electoral Commission Ghana 2005). Ironically, it has been argued that, though ethnicity has played an important role in the political history of Ghana, its role in this respect may not be as salient as perceived in the current political landscape of Ghana. Cohen from a theoretical perspective has been reported to note that "the most important principle underlying most African election studies has been a census that African voters tend to make their electoral choice as communities rather than individuals" (Cohen 1993: 80, Krutz 2005: 13). Krutz in his paper, "Determinants of Party Support in Ghana's Fourth Republic" noted that, "an approach to Ghanaian electoral politics that focused solely or perhaps even primarily, on ethnicity and access to particularistic benefits seems limited". Krutz indicated that Ghana differs from Nicolas Van de Walle's characterization of the modal African political party system, in which a dominant party is surrounded by tiny, evanescent opposition groupings (Van de Walle 2003). According to Krutz, analyses of data from the Afrobarometer survey conducted in Ghana in 1999 and empirical testing of four different hypothesis, showed that "it is clear from 
the most cursory examination of vote data and anecdotal evidence that ethnicity and particularistic benefits certainly do have a central role in Ghana's electoral politics even though other individual-level variables, such as ideology, retrospective evaluations of incumbent performance, sex, economic well-being, religiosity, and age, might be relevant". Krutz however, concluded that there is marked variation in Ghana with regard to major ethnic groups' tendencies toward communal voting and major parties' bases of support. Additionally, the other variables, such as age, economic well-being, education, retrospective evaluations of incumbent performance, and measures of support for particular economic policies, were also significantly correlated with party support.

Chazan, earlier on had echoed the role of ethnicity in Ghana's electoral politics and stated that the exacerbated political manifestation of ethnicity so apparent in the 1970s prompted Rothchild to comment that, "of all the highly significant cleavages of modern Ghana (sub -region, age, class, income, education and so forth) none is more salient than that of ethnicity" (Rothchild, 1978: 1, Chazan 1982: 461-485). Krutzt again states that many observers have long suggested that ethnicity is an important factor in electoral politics in Africa and goes on to cite Kwesi Jonah as noting that "to ignore the ethnic factor is to ignore a major key to understanding the mind of the Ghanaian Voter (Krutzt 2005: 14, Jonah 1998: 246). According to Hauer (2004), organizations based on ethnicity in many different ways strengthen the democratic development in Ghana through the home-town associations, which work through the pluralistic system.

On the contrary, Ayee stated in a most recent post elections analysis paper that though the general perception has been that ethnic undercurrents played a major role in the success of the winners in Ghana's 2004 elections, examination of the validity of this assertion suggested that "explaining electoral outcome in terms of ethnicity amounts to 'uni-causal reductionism' that seems to have no strong empirical basis" (Ayee and The Electoral Commission of Ghana 2005: 92). Despite the fact that some authors, analysts and politicians have tried to down play the effects of ethnicity in Ghanaian electoral politics in recent times, some other studies seem to suggest something different. To what extent is ethnicity still influencing the prospects of political parties in Ghana? What is the connection between ethnicity and the outcomes of political marketing strategies of political parties in Ghana? There is the need to analyze trends in the current political landscape of Ghana in order to deepen understanding and validate knowledge about the key factors that drive voter choice in Ghana. This is deemed to enhance the consolidation of democracy in Ghana. This study of the role of ethnicity in determining voter behaviour against the major political marketing dimensions though not conclusive is envisaged to present some potent and relevant arguments regarding political trends in Ghana. However, the purpose of this paper is to reflect on the relationship, if any, between ethnicity and key political marketing dimensions and to suggest how these factors may influence the fortunes of major political parties in Ghana. Understanding the role of ethnicity in modern Ghanaian politics would also enhance the development of political marketing strategies and further deepen democratization in Ghana.

The paper focuses on analyzing the effects of ethnicity on voting patterns in Ghana. It seeks to compare the results of the four different elections of the Fourth Republic of Ghana. It further attempts to make inferences on the effects of ethnicity on the voting patterns of the four (4) Presidential elections in the Fourth Republic. Again, though not conclusive, the analysis seeks to use the voting patterns as a pointer to the acceptability and effectiveness of a political party's marketing approach. It compares the effects of the political product characteristic, Political Product Benefits or the Political Marketing Support Services and focuses on variables like political philosophy, party character, manifesto, political party leadership and previous performance on elections outcomes among identified or classified ethnic groups and at regional or communal level. It also reflects on experiences gathered in managing presidential campaigns in Ghana.

The paper seeks to compare performance of the two key ethnic based political parties in the four presidential and parliamentary elections of the fourth Republic of Ghana in all the ten regions in Ghana.; to analyze outcome of the two political parties in urban (ethnically mixed) and Rural (ethnic based) constituencies; To reflect on major factors resulting in gains or losses of the two political parties in the various regions. 


\section{POLITICAL MARKETING FUNCTIONS AND DIMENSIONS}

Political Marketing has been described as marketing designed to influence target audiences to vote for a particular person, party, or proposition. There have been various attempts to clearly define political marketing, however the essence of political marketing theory remains somewhat opaque (Scammell 1999; Newman, 2002; O'Shaughnessy and Henneberg, 2002a, O'Shaughnessy 1990; Kotler and Kotler, 1999).

Contemporary definitions of political marketing often identify the political marketing process as concerned more with the communication process between voters and political entities (Shama, 1975; Lock \& Harris, 1996; Wring, 1997) and often neglect the organizational development perspective of the political entity in a way that most commercial marketing definitions do not. Lee - Marshment (2001) in redefining political marketing states that political marketing goes beyond the spin and campaigns of political parties and also covers the role of market intelligence in policy, leadership and organization of political parties.

The application of commercial marketing techniques and tactics to elections is considered to be relatively new and still in the infant stages in many parts of the world (Henneberg 2004, Marland 2003). However, the relevance of particular aspects of marketing theory for political entities has been illustrated by numerous authors. Again, LeeMarshment describes four main activities that a party attempting to use marketing in determining all aspects of its behaviour has to engage in. These include the use of market intelligence, adapting party behaviour to suit those whose support it seeks, implementing this new behaviour at all levels of the party organization and conveying this to the electorate (Lee - Marsment 2001). Henneberg (2002: 123) also describes eight generic political marketing functions which include, product function, distribution function, cost function, news management function, fund raising function, communication function, parallel campaign management and internal cohesion function. He also proposes six general applications of political marketing for most democratic systems as communication and spin, product image management, news management, political marketing strategy development, political market research and political market organization and professionalism. Henneberg argues that a 'Market-Oriented Party' (MOP) is one which seeks to determine its entire behaviour in order to provide voter satisfaction and in doing so satisfy its own goals.

In both the four core activities and eight functions of political marketing described by Lee - Marshment and Hennerberg, the marketing-in concept is employed. This means that the political product should be designed to fit into both the social and economic context of the target audience whose votes that particular political party is seeking. This reveals the practicality of the product versus the environment in marketing theory, the marketing mix that is the Product, the Place, Price and Promotion as well as the People. However, the pivotal role of both the product and the place in the Marketing mix can be deduced, since both promotion and price are dependent on the product and the place where it is to be marketed, whereas the product design is determined by the expectations of the people for whom the product is designed. Two key factors sell a product; the characteristics of the product itself and how it is promoted.

The political party which seeks votes of electorate in a defined environment by deduction can be considered the political product. Given that every product has its own characteristics or features, the characteristics of a political product which include personalities, philosophy or ideology, manifesto, past performance, dependability, reliability, and brand name or image can be said to determine the acceptability of that product within the defined environment. However, by the dimensions of competition, product characteristics go beyond the mere physical features of a product as listed above to include extrinsic components like brand name or product image and also product support services which in this case may include news management, media relation, communication management and product distribution and other promotional activities, which constitutes the campaign.

The environment, to a very large extent, describes the people, their beliefs, economic and social disposition. These concepts are also considered to be fundamental to ethnicity. Acceptability of a political product can be said to be tied to the extent to which that political product satisfies the needs and aspirations of its potential buyers, that is voters. In this case, both the product dimensions and environment can be considered key determinants of the acceptability of the political product. Acceptability of a political party to a large extent can therefore be said to be tied to how such a defined environment identifies with a particular political party based on the product characteristics that 
is personality in terms of party leadership, party structure, ideology or philosophy and party image and past performance. While what goes on during electioneering campaigns can be said to constitute the promotional aspects of Political Marketing. Thus, acceptability of a political party in any defined environment can be considered the basis or the very source of any meaningful showing of a political party in an election, while the campaigns complement acceptability for actual gains.

Lott and Reed stated that the political market is composed of voters, challengers and incumbents (Lott and Reed). The political market can said to be any where political parties and electorate meet or communicate to sell and buy political products. Here the electorates constitute the buyers while the political parties constitute the sellers and within that environment there are also competitors with their own strengths and weaknesses except in a one party state. The key considerations in political marketing would be, what product, how is the product presented, where is the communication or buying taking place, who is the potential buyer and at what time is the communication taking place? The political market can be described here as the actual target audience being sought by a number of political parties which can never be generic but specific to the group being targeted within a particular environment. In political marketing, the battle field is the mind set of the voter whereas in a society where ethnicity and communality plays a vital role, the political market can bed said to be the mind set of the floating voter, given that that party already has a strong basis. This is where the role of ethnicity falls in Political Marketing. By reflection, ethnicity, which relates people of common origins, culture, values and aspirations can be linked to political marketing. To what extent does segmentation of the market and therefore communal identity or ethnicity influence political marketing approaches? Can the ACORN ${ }^{1}$ effect be described as the basis of the communal voting pattern reported to be emerging in Ghana? What relationship can be established between the ACORN effect and ethnicity in Political Marketing in Ghana?

\section{ETHNICITY AND POLITICS IN AFRICA}

Ethnicity pervades every society and is therefore essential or fundamental to every political marketing approach even though to a lesser extent in more mixed environments. Ethnicity is equally not a simple concept to theoretically define. Operationally however, ethnicity or an ethnic group can be defined as a collective of people who share some patterns of normative behaviour and form a part of a larger population that are interacting with people from other collectives. In this way, ethnicity refers to the degree of conformity by members of the collective that share norms (Cohen, 1993). Ethnicity has also been described as individuals identifying themselves with a collective of people with whom they share patterns of normative behaviour and feel solidarity with (Hauer, 2004).

As a social identity, the effects of ethnicity result in both gain and loss interactions affecting marketing outcomes. In this way, it has both positive and negative effects on organizational strategies and marketing approaches of political parties. Political parties use various tools and techniques to learn much about people's identities and culture as much as possible, in order to tailor their pitches for candidates to win the acceptability of such people. Likewise the performance and acceptability of political parties among particular ethnic groups is tied to the perception, appreciation and how the ethnic group identifies with the party.

Ethnicity is by implication considered and identified as one of the important issues affecting democratization and nation-building on the continent of Africa. It is believed to have had great impact, in fact more impact than other factors, on how politics and nation-building processes are pursued in Africa. The issues of religion and ethnic identity are said to have dominated the politics of democratization and nation-building in Africa. "The complexity of ethnicity in African grass root politics is due to the fact that African ethnic groups bond not only by kinship, but also by principles" (Nyuot Yoh, 2004).

\footnotetext{
${ }^{1}$ ACORN (A Classification of Residential Neighbourhoods)), which classifies people by where they live and is based on the idea that "birds of the same feathers flock together". This theory gives recognition to the fact that people with broadly economic, social and lifestyle characteristics tend to congregate in particular neighborhoods and exhibit similar pattern of purchasing behavior and outlook.
} 


\section{POLITICAL HIGHLIGHTS OF GHANA}

Ghana's political experienced can be described as a chameleonic experience. It has been full of regime changes, both democratic and authoritarian. Ghana gained independence on the $6^{\text {th }}$ of March, 1957 after more than four centuries of colonial rule under the Portuguese, Dutch and British. The Gold Coast as Ghana was known before independence is described to have been considered a showpiece of British Colonies, the richest, the best educated, and the first to have an elected majority legislature with best organized native authorities (GISD 1994).

Ghana spear headed the political advancement of Africa with her first president Dr. Kwame Nkrumah laying the foundation for an African unity. With all this promising political background the State of Ghana was beset by political instability for over 30 years before achieving the current degree of stability. In summary, Ghana has had a 16year multiparty system, a twenty one (21) year military system and six (6) years of one party system. An overview of Ghana's political experiences is outlined below.

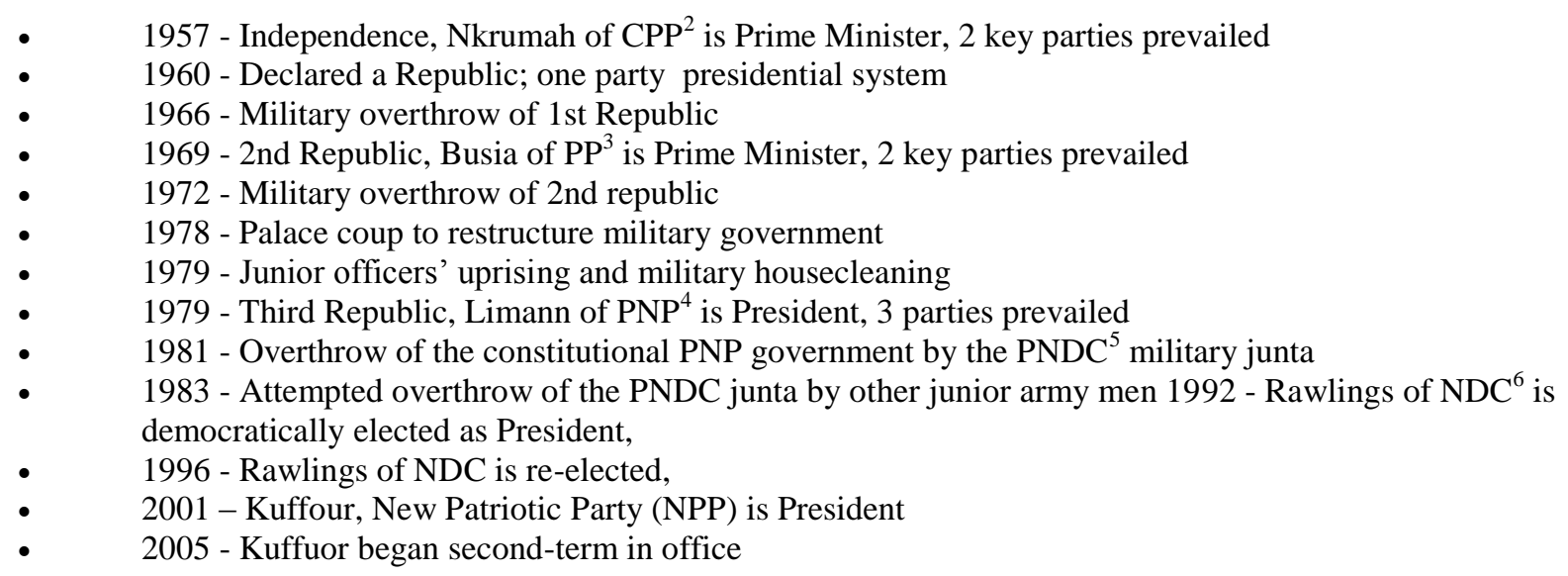

(Extracted from GISD booklet 1994, Ghana Web 2006)

\section{Ethnicity And Politics In Ghana}

The effects of ethnicity and its specific role in current partisan politics of Ghana is under debate by researchers, political analysts and critics. Though ethnicity is perceived by some to be pivotal and still very salient in Ghanaian electoral politics, some recent studies are pointing to the fact that ethnicity may not be as salient as is being purported by others. While it has been described as being the most salient cleavage in 'Pre- Fourth Republic Ghana', others suggest there are currently marked variations in the propensity of major ethnic groups toward communal voting and the basis for the support of major parties, while others suggest that there is no strong empirical evidence to confirm its current perceived role. The questions are; To what extent is ethnicity still influencing the prospects of political parties in Ghana? What is the relationship between ethnicity and key political marketing variables in determining political marketing outcomes of major political parties in Ghana?

In 1960, roughly one hundred linguistic and cultural groups were recorded in Ghana (Hauer 2004, Ghanaweb 2004). Krutz in his recent paper also stated that there are about ninety two ethnic groups in Ghana (krutz 2005). Although after the 1960 census, other censuses placed less emphasis on the ethnic and cultural composition of the Ghanaian population, there are marked differences which still exist. On the basis of language and culture, the people of Ghana can be classified into five major ethnic groups. These are the Akan, the Ewe, MoleDagbane, the Guan, and

${ }^{2}$ Convention People's Party

${ }^{3}$ Progress Party

${ }^{4}$ People's National Party

${ }^{5}$ Provisional National Defence Council

${ }^{6}$ National Democratic Congress 
the Ga-Adangbe (Yalae, Papa: 2006). The Akan groups constitute about 49.1\%, Mole-Dagomba 16.5\%, Ewe 12.7\%, Ga-Dangme 8\% and non-Ghanaians 3.9\% (2000 Census). Within each ethnic group are sub - ethnic groups some of which are considered Traditional African States on their own. These sub ethnic groups are separate and politically organized but traditionally have no political allegiance to one another (Yalea 2006).

Ethnicity has been recognized as a central principle in Ghanaian social life and the most Salient significant cleavage in modern Ghanaian history (Ayee 2005: 85, Rothchild 1978:1). Ethnicity has been depicted to be one of the most potent factors affecting political behavior in Ghana and it is believed by some to virtually dominate political discourse in Ghana today. Political alignments in Ghana can be said to have followed ethnic and religious interests rather than any other concerns. Ethnicity and Religiosity in Ghana's politics can be traced back to pre-independence and independence era (Yalea 2006). "The formation of regional, religious and ethnic based parties and organizations such as the National Liberation Movement, Northern People Party, Togoland Liberation Movement, Moslem Association Party and Ga Shifimoo Kpee before and immediately after independence" (Frempong, 2001) depicts the role of ethnicity in Ghanaian politics. According to Chazan, the ethnic composition of Ghana's seven regimes has been varied". Chazan contends that "Control of state power moved from the southern Akan during the Nkrumah years, to a $\mathrm{Ga}$-Ewe Coalition, under the National Liberation Council (NLC); then to a central Akan (Ashante-Brong) alliance of Busia, to a more ethnically balanced National Redemption Council (NRC)-Supreme Military Council (SMC) Coalition; then to a Minority agglomeration with a disproportionate Northern representation in the administration of the Third Republic and then finally to a heavily Ewe based PNDC, which became the National Democratic Congress (NDC) also considered Ewe Based" and now the highly considered Akan based National Patriotic Party (Chazan 1982, Yalae 2006,). According to the post election report by the Electoral Commission of Ghana, manifestation of ethnicity is still considered to be prevalent in Ghanaian politics and the shared feeling of belonging to a nation is recent though the report concluded that explaining electoral outcome in terms of ethnicity amounts to "uni-casual Reductionism" that seems to have no strong empirical basis (Republic of Ghana 1991:50, Ayee 2005: 85).

It has been asserted that the only time that Ghana had a true national party was during the first Republic under Kwame Nkrumah's one party system of governance. All others have been branded as ethnic based (Yalea 2006). Most presumably, the lack of a strong ethnic support base can be said to account for the instability and poor showing of the Nkramaist tradition which is highly fragmented today. Yalae indicated that the entrenchment of ethnicity in Ghana's politics is due to the fear of perpetual ethnic domination in the politics of Ghana. It is the fear of ethnic subjugation by another ethnic group as a result, "there has been no true national political party in Ghana since the demise of the Nkrumaist Party, the Convention Peoples Party (CPP) in 1966. "The New Patriotic Party - NPP and its predecessors since independence are seen by many as an Akan Party dominated by the Akan sub-ethnic group, the Asante, while the National Democratic Congress - NDC and its predecessor are seen as the Ewe Party, although the recent presidential candidate is Akan. The current Nkrumaist Party - CPP and PNC - Peoples National Congress, unlike their predecessor, also do not reflect a national party" (Yalea 2006).

The effects of ethnicity in politics is however not limited to Ghana. It has been described as a dominant factor in African democratic or electoral politics, which has also, been conceptualized as a largely communal affair (Cohen 1983: 80). Krutz notes that "affective identities, including ethnicity, kinship group, and religion, have been cited as important factors driving vote choice and party support in many studies of post independence Sub-Saharan Africa. (Krutz 2005: 13)

Yalea contends that "although, ethnically based political parties are unconstitutional under the present republic of Ghana, ethnic sentiments in the politics of Ghana have not subsided but are on the increase". A number of interventions have been employed since the first republic to reduce the manifestation of ethnicity in Ghanaian politics. However, even though some theoretical evidence have been advanced to the extent that the effects of ethnicity in present Ghanaian politics may not be as salient as purported (Krutz 2005, Ayee 2005), some substantial empirical evidence is revealed by trends in the voting patterns of the four elections in the fourth Republic of Ghana to the extent that ethnicity is portrayed as playing a dominant role in the fortunes of political parties. 
Some analysts have contended that ethnicity being a socio-political need is a major factor in Ghanaian politics and this was vividly demonstrated by 2004 elections. According to Yalea "the loss of the 2004 elections by the NDC was due to ethnicity, not because of internal ethnic strife for the control of the party, but because of external perception - the prevailing perception of the Akan ethnic group that the NDC is a party controlled by the Ewe ethnic group". Yet, Ayee from his recent analysis argues that ethnicity is not very important in winning elections in Ghana and concludes that it is difficult to explain the 2004 election results and previous ones solely on the basis of ethnicity. What other variable drive voter behaviour in current Ghanaian electoral politics and to what extent?

\section{Political Marketing In Ghana}

Theoretically, the political market of Ghana can be said to be the total number of registered voters against the total numbers of registered political parties contesting an election. However, in practice the political market in Ghana can be said to be dominated by twenty percent $(20 \%)$ of the total electorates which constitute the floating voters most of whom can be found pre-dominantly in relatively mixed communities and urban areas mostly in the swing regions ${ }^{7}$. The Pareto $80 / 20$ rule can be said to apply here. This is because $80 \%$ of the Ghanaian electorate seems to be loyal to either of the two major political parties as revealed by a cursory examination of election results in the Fourth Republic.

The data further reveals that aside the 1992 and 1996 elections, in which the difference in the total number of votes between the two major and perceived ethnic based parties was more than $20 \%$ and just about $20 \%$, the differences in all the other three presidential election results are less than $10 \%$. The difference in this case can be attributed to the Rawlings personality which can be said to be still relevant in Ghanaian electoral politics. About $80 \%$ of the Ghanaian electorate in the fourth republic can therefore be described as party loyals or party faithfuls either because of the political product attributes, the political product benefits or the political marketing support services all of which include specific variables like the effects of people and place (ethnicity), personality, past performance, party identity or image, and campaign among others.

Each of the two major parties to begin with, has about $40 \%$ plus or minus 5\% votes, and has to position itself to pool at least an additional $10 \%$ or more votes in the presidential election in addition to maintaining their baseline to win the elections. Hayes \& McAllister (1996) have pointed out that floating voters can essentially be regarded as "individuals with no brand loyalty" which supposes that it would be relatively more difficult to win such votes. In marketing though it is said that it is more difficult to maintain a customer than to win a new customer, in the case of political marketing it can be said to be the other way round, where it is more difficult to win a floating voter than to maintain a party faithful and this is why campaigns are so important. This is because it is difficult to determine what the expectations of floating voters are in order to satisfy them. Ability to maintain "party faithfuls" and in addition gaining a little above ten percent of floating voters therefore can turn around the fortunes of a political party positively in Ghana. Smith \& Saunders (1990) stated that in the integrated marketing era the future of political marketing will further identify the target markets' wants and needs and the necessary policy decision-making to satisfy these wants more effectively (Newman, 1994a; Kavanagh, 1995; Scammell, 1995; Holbrook, 1996; Butler and Collins, 1999; Baines and Egan, 2001; Johnson, 2001; Lees-Marshment, 2001),

This is where combining the political marketing variables which include the Political Product Attributes, Political Product Benefits and the Political Marketing Support Services become relevant. The political marketing context in this case is how the political parties tailor their pitches to win the votes of the electorate concerned. Using the normative theory of segmentation, the dynamics of every market determines the strategies to deploy. The marketing planner must recognize that the customer and product characteristics should determine the marketing strategy. In political marketing the customer characteristic may refer to the variables that can be used to understand the particular market segment and these include the geographic and geo-demographic considerations, as well as demographic, behavioral and psychotropic considerations. The geography refers to the region, climate, population density while the geo-demographic considers ACORN (A Classification of Residential Neighbourhoods)), which

\footnotetext{
${ }^{7}$ The five swing region which also have always gone with the winning party are; Greater Accra, Broang Ahafo, Eastern, Western and Central Regions.
} 
classifies people by where they live and is based on the idea that "birds of the same feathers flock together" (Wilson et al 1993). This theory gives recognition to the fact that people with broadly economic, social and lifestyle characteristics tend to congregate in particular neighborhoods and exhibit similar pattern of purchasing behavior and outlook. The use of ACORN as a segmentation base for voter targeting has been describes by a number of authors (Yorke \& Meehan, 1986, O'Leary \& Iredale, 1976),). The Behavioral factor considers attitudes, knowledge, benefits, user status, loyal status and readiness to buy; while Psychographic factor considers, Personality, Lifestyles etc (Wilson et al 1993: 202). When most of these factors are put together the sums can be equated to ethnicity or communality. This is because both ethnicity and communality reflect, not only the people, but the place, their, believes, culture and values and their purchasing abilities.

Theoretically therefore, it can be presumed that the political marketing strategies of a political party should consider the characteristics of the community or constituency, the lifestyle and attitudes of the people whose votes are sought, their loyalty which to a large extent would be tied to ethnic considerations or history of that political party and benefits which include either past, immediate or long term benefits and finally presentation which relates to how the political party packages messages and its image as well as other promotional activities. Using the marketing mix theory, the role of the product, the place, the price, the promotion, the people, the process and the physical evidence becomes even more relevant in political marketing. The place and the people can be said to constitute the effects of ethnicity or communality (ACORN) in political marketing, the process is the internal party processes, the physical evidence is the past performance and immediate benefit attraction while the product is the political party itself with all its attributes like personality of leadership, ideology, manifesto, party identity among others. The political price can be described as the quantitative financial expression of what it actually takes for a party to organize itself, maintain itself and gain at least the minimum required votes to win an election in a specified country or constituency. Since political parties seek to sell themselves, the political product is a political party vying for an election. In designing a political product therefore, this has applied the principles of Kotler (1988).Kotler (446) suggests the consideration of three distinct elements which when applied to political marketing become the political product attributes, the political product benefits and the political marketing support services.

In recent elections however, political marketing strategies in Ghana have focused more on political marketing support services mainly, media relations, news management, campaigns, particularistic benefits and other promotional activities leaving product design and presentation to ethnicity, religiosity and personality.

In deciding on leaders of the party, particularly the flag bearer and vice presidential candidates, the major consideration has been which ethnic card to play, the NPP has persistently settled for an Akan flag bearer and a Northern vice though in 1996 it was an all an Akan permutation. The NDC which on the other hand is generally perceived as an Ewe based party has been rather relatively more heterogeneous in its leadership and normally looks for means to balance the Akan factor which is the largest and dominant ethnic group in Ghana. When the NDC had an Ewe flag bearer it chose in both cases Akan vice presidential candidates. With an Akan flag bearer the NDC settled for Northern running mates in both the 2000 and 2004 elections. The next consideration is the religious card. Each of the parties tries to balance between Christianity and Islam religions in a number of presentations at party leadership, flag bearer or vice presidential slots. The design of the product goes further to include how national, regional and constituency level ranking members of the Parties are selected and their relationship with the file. Other features engaged in designing the political product in Ghana include, Party ideology, Party manifesto, the personality of the Flagbearer and Parliamentary candidates, Ethnicity, Message, and communication in this case pivoted on the relationship with the press.

Presentational strategies in marketing political parties in Ghana hinges on promotion, Party image and Party origin are also tools used in the campaigns. For example, the NDC has been persistently tagged as a violent and non elitist party and presented as a pro-poor; Ewe based national party with a largely rural and urban poor support base. The NPP has been tagged as non national pre-dominantly Akan based Party and presented as an elitist, property owning Party with a largely urban support base. The issue is how these market segmentation and political product variables adjust the prospects of political parties in Ghana. 


\section{Ethnicity And The Voting Pattern In Ghana}

No part of Ghana is ethnically homogeneous and the urban areas are the most ethnically mixed, because of migration of those in search for employment. Huaer, stated that with the exception of cocoa-producing areas that have attracted migrant labor, rural areas tend to reflect more traditional population or indigenous distributions (Huaer, 2004:26). Analysis of the voting pattern indicated that aside the Ashanti, Volta Western Regions no particular party can consider any of the urban districts or constituencies as a stronghold because of the ethically diverse nature of these constituencies. This presupposes that effects of ethnicity would be more pronounce in rural areas. Subsequently, it follows that using the swing regions to analyze the effects of ethnicity may be quite misleading. As a result this analysis focuses more on voting pattern in the non Swing regions and where necessary, considers trends in the swing regions. The five swing regions which have always gone with the winning party in the Fourth Republic are Brong Ahafo, Eastern, Western and the Central Regions respectively, whereas the non Swing

Regions are The Ashante, Volta, Northern, Upper East and Upper West Regions respectively. The Ghana Statistical Services Department reported that the Greater Accra, Ashanti, and Western Regions have tended to be net receivers of migrants while the Central, Volta, Upper East and Upper West are areas of net out-migration. Ironically, following this analysis, it looks specious that the Ashante Region which is classified a net receiver of migrant and the second most urbanized region in Ghana and the Central Region which is also considered a net out migration area tend to be non - swing and swing regions respectively. However, these trends can be explained on the basis that the Central Region is considered the cradle of education in Ghana with the highest number of secondary and tertiary institutions having a considerable number of boarding students who tend to register and vote in this region. This is believed to explain the urban and ethnically diverse tendencies revealed in the voting trends of the Central Region. Again, even though the Ashanti Region is quite urban, by virtue of it's location, it's population may not be as ethically diverse rendering it an ethnic based region.

Trends of the four presidential elections suggest that for any political party to win Presidential Elections in Ghana it must have an ethnic base as a spring board. The results indicated that though several factors contribute to the performance of political parties, ethnicity plays a major role in the acceptability of the political marketing approaches. This is because since 1992, total valid votes cast in all five non-swing regions which are generally considered to reflect more traditional population or indigenous distributions and where ethnicity is expected to be more pronounced has been more than $40 \%$ of total votes cast nationally. This by deduction would mean that a significant $40 \%$ or more of the total votes in all four presidential elections in the fourth republic are highly dependent on ethnic consideration going by the ACORN Theory.

The analysis made it apparent that political parties with very strong ethnic support bases are those that have stood the test of time no matter what marketing tools or approaches are employed. The case of the Nkrumaist Party considered the only true national Ghana has have and the demise of the CPP supports this assertion. The NPP has survived because of the Busia Dankwa Tradition a typically Akan Tradition. The NDC has survived because of the Rawlings - Volta factor. These two parties have survived and are being sustained because they have strong holds as a result of ethnic ties. Strongholds are considered pre-requisites for multiparty systems imperative for the sustenance of political parties. In all the four elections of the Fourth Republic of Ghana, both the NDC and NPP won overwhelmingly in the Volta and Ashanti Regions respectively, the ethnic based regions for the two parties. However, there are some significant differences in the total votes pooled in these regions by each party in all four elections.

In both 1992 and 1996, Rawlings son of the soil of the Volta Region pooled above 90\% of the votes in both elections and almost 33\% in both cases the in Ashante region on behalf of the NDC while the NPP votes in the Volta Region in both cases were below 5\% but $60.5 \%$ and $65.8 \%$ in Ashanti Region respectively. However, in the 2000 and 2004 elections, Atta-Mills pooled $86.81 \%$ and $83.8 \%$ respectively in the Volta Region and $22.7 \%$ and $24.0 \%$ in the Ashanti Region Respectively. With a Change in leadership personality, the performance of both parties in the rival Regions changed considerably. The trend suggests the role of both ethnicity and personality in Ghanaian elections. The differences between the 1992, 1996, 2000 and 2004 votes in the Volta region by the NDC can be attributed to ethnic ties between the Region and Rawlings son of the soil. Though it can be said that generally Ewes identify with the NDC, the exit of the Ewe personality as flag bearer caused a slight but considerable shift in the fortunes of the 
party in that region. Again, the relatively higher showing of the NDC in the Ashanti Region as opposed the NPP in the Volta Region can be attributed to two factors, the urban nature of the Ashanti Region which is about $51 \%$ urban and $49 \%$ rural though ethnicity can be said to be very prevalent in this region. The Ashanti Region as already stated has been classified as a net receiver of migrants. In addition to this, the ethnic ties with Nana Konadu Agyeman Rawlings a daughter and royal of the soil of Ashanti and wife of Mr. Rawlings further establishes the role of ethnicity in voter choice in the region. In contrast, though some have argued that the poor showing of Atta-mills son of the Central Region in both the 2000 and 2004 elections confirms the fact that winning elections in Ghana goes beyond winning elections in the parties mere constituencies or regions and therefore that this evidence downplays the effects of ethnicity in Ghanaian politics, this argument seem not to have a strong logical basis. As already stated, even though the Region is classified as a net out migrant area, and therefore supposed to reflect a more traditional population or indigenous distributions which is predominantly ethnic based, the voter population is relatively ethnically diverse because of the number of secondary and tertiary institutions in that region. Besides, it has been suggested that the Central Region did not reject their son but rejected the NDC, based on fear of ethnic domination because of the prevailing perception that the NDC is a party controlled by the Ewe ethnic group. A vote for the NDC in this view may perpetuate an Ewe domination of power in Ghanaian politics.

It has also been suggested that the NPP won the 2004 elections in areas with about $40 \%$ Akans while Regions with 2 to 10\% Akans voted for the NDC. (Ayee 2006: 92) Though Ayee, agues that this suggestion is patchy and as a result not convincing enough, a careful analysis of the election results seem to suggest something different. The five swing regions which move with the winning party are all more than $30 \%$ urban and less than $70 \%$ rural and all these regions seem to reflect a relatively high level of ethnic diversity. It is quite leading to note that the Akan ethnic group alone constitutes about 49.1 percent of the total population of the country and covers typically five of the ten Administration Regions in Ghana. Ironically four of the five swing regions are all Akan based except the Greater Accra Region where the Akan presence is equally strongly felt. However, it is interesting to note that, all the five Akan based regions exhibit a high level of ethnic diversity reflecting in their swing tendencies. Again only one of the five Akan based Regions is classified net out Migrant area, that is the Central Region even though this effect seem to be nullified by the high number of students who vote in that region. Even a cursory view of the election results reveals that generally the NDC tended to reflect more ethnic diversity than the NPP. This is because the Ewe Ethnic group which forms the ethnic home of the NDC constitutes only $12.7 \%$ of the total population of Ghana and alone Ewes cannot give the NDC the total of $40 \%$ or more of total valid voters that have demonstrated to be loyal to the NDC. (See Appendix 1 for vote dispersion). Krutz in his recent work established that the NDC party drew less than a fifth (17.6\%) of its support from the Ewe ethnic group. It is therefore evident that the NDC is not an Ewe party though can be described as an Ewe based party. The NPP on the other hand cannot also be described as an Akan Party but as an Ashante based party. Krutz indicated that in testing the hypothesis on the effects of ethnicity on electoral politics in Ghana, $93.1 \%$ of Éwés who professed an affinity to one of the two major political parties selected the NDC, while only $6.9 \%$ felt closer to the NPP. Akans were reported to be much more evenly split, with $53.4 \%$ supporting the NPP and $46.6 \%$ the NDC. Again the NDC is reported to draw almost a majority of its support (45.9\%) from Akanspeakers. This contrasts sharply with the NPP, which draws nearly $80 \%$ of its support from Akans; however, it is presumed that this identity is split in a politically salient way between Twi and non-Twi. Further more, Krutz report indicated that $73.7 \%$ of those identified as Ashanti who identified a party affinity selected the NPP, while only $26.3 \%$ selected the NDC. These findings reinforce general understandings of the Ashanti group as heavy NPP supporters (and NDC opponents). Besides, and perhaps more interestingly, the data suggest that non-Twi-speaking Akans did not participate in electoral politics on a communal basis. While $47.7 \%$ of these non-Ashanti individuals who expressed affinity for a party chose the NPP, a nearly identical number (52.3\%) chose the NDC. It therefore concludes that, while Akans as a whole tended to lean toward support for the NPP, non-Ashanti Akans leaned slightly toward the $N D C$. Smaller ethnic groups, including the Dangaare, Dangbane, Ga, Hausa, and Frafra, also seemed to lean toward the NDC.

Political Products Benefits and the Political Marketing Support Services have been shown to have limited effect on voting pattern in Ghana though Political Product Benefits seem to be more salient than the Political Marketing Support Services. The alleged vote buying in the Volta Region in the 2004 election by the NPP did not seem to influence NPP performance in that region much. In addition the NDC purported largesse and PORK spending in the 2000 election has been proven to have had very little effect. Rather, the identity of the party in the case of the 
NDC, concern for the poor and in the case of the NPP, property owning which in theoretical terms describes part of the features of the Political Product, drives voter behaviour to a large extent. Rural and urban poor voters feel they are more secured with the NDC than with the property owning NPP and vice versa for Urban Elitist voters. It is argued that Ghana's Structural Adjustment Programme (1983-92) was distributionally favourable to rural households and unfavourable to urban households. A link is therefore drawn between the distributional impacts of the Structural Adjustment Programme and the voting patterns of rural and urban households (Bawumia 1994, Krutz 2005) casting a shadow of (P)NDC past performance. (See Appendix 3 for PORK spending). Available evidence indicate that the Ashanti Region had the highest share of development projects under the NDC regime but NDC had least votes in the Ashanti Region in the 1992, 1996 and 2000 elections. Rawlings on the other the other hand is reported to have expressed regret for not doing much in terms of development for the Volta Region yet NDC got highest votes there (Ayee 2005). The five regions predominantly rural reflect identities with NDC while the five regions with relatively urban tendencies reflect communal tendencies.

\section{CONCLUSION}

In conclusion, it could be suggested that despite the fact that several factors contribute to the performance of political parties in Ghana, ethnicity plays a major role in the acceptability of political marketing approaches. This features quite prominently in the ethnic based voting pattern that has prevailed over the years and the communal voting pattern that is emerging in Ghana as a result of increasing urbanization. The analysis makes it evident that political parties with very strong ethnic support bases are those that have stood the test of time no matter what marketing tools or approaches are employed though political marketing gains to a large extent depends on the features of the political product. Ethnicity can be summarized as the pre-requisite for the sustainability of a political party in Ghana. In addition personality, perceived image or identity of the political party and media relations are the key features that play a vital role in determining political marketing outcomes or fortunes of a political party and to some extent political product benefits based on past performance and experiences whereas effects of particularistic benefits that is party paraphernalia or the political marketing support services and manifesto are less prominent.

\section{APPENDIX 1}

Table 1

Distribution Of Votes In The Strong Holds Of The Two Dominant Political Parties In Ghana In All Four Elections In The Fourth Republic

\begin{tabular}{lcccc}
\hline & \multicolumn{2}{c}{\begin{tabular}{c} 
NDC/NPP \\
\multicolumn{1}{c}{ Votes Distribution in Volta Regions }
\end{tabular}} & $\begin{array}{c}\text { NDC/NPP } \\
\text { Votes Distribution in Ashante Region }\end{array}$ \\
\hline YEAR & NDC & NPP & NDC & NPP \\
1992 & 93.2 & 3.6 & 32.9 & 60.5 \\
1996 & 94.4 & 4.7 & 32.8 & 65.8 \\
$2000^{8}$ & 86.8 & 6.6 & 22.7 & 75.6 \\
$2000^{9}$ & 88.5 & 11.5 & 20.1 & 79.9 \\
2004 & 83.8 & 14.2 & 24.0 & 74.6 \\
\hline
\end{tabular}

Source: Electoral Commission, 2005

\footnotetext{
${ }^{8}$ Election 2000 (Main Election)

${ }^{9}$ Election 2000 (Run-off)
} 


\section{APPENDIX 2}

Table 2.0

Distribution Of Votes Of The Two Major Political Parties In All Ten Administrative Regions In Ghana In All Four Elections In The Fourth Republic

\begin{tabular}{|c|c|c|c|c|c|c|c|c|c|c|c|c|}
\hline \multirow[b]{3}{*}{ Region } & \multicolumn{2}{|c|}{ Votes $(\%)$} & \multicolumn{2}{|c|}{ Votes(\%) } & \multicolumn{2}{|c|}{ Afrobarometer } & \multirow{2}{*}{\multicolumn{2}{|c|}{$\frac{\text { Votes (\%) }}{2000 \text { (Main) }}$}} & \multirow{2}{*}{\multicolumn{2}{|c|}{$\frac{\text { Votes (\%) }}{2000 \text { Runoff }}$}} & \multicolumn{2}{|c|}{ Votes (\%) } \\
\hline & 1992 & 1992 & 1996 & 1996 & 1998 & 1998 & & & & & 2004 & 2004 \\
\hline & NDC & NPP & NDC & NPP & NDC & NPP & NDC & NPP & NDC & NPP & NDC & NPP \\
\hline Western & 60.7 & 22.8 & 57.3 & 40.9 & $50.10 \%$ & $50 . ' 0 \%$ & 43.95 & 50.5 & 39.1 & 60.90 & 40.8 & 56.6 \\
\hline Central & 66.5 & $26 . ' 0$ & 55.7 & 42.9 & 91.'0 & 9.'0 & 43.73 & 49.7 & 39.69 & 60.31 & 39.2 & 58.8 \\
\hline Gt. Accra & 53.4 & $37 . ' 0$ & 54.'0 & 43.3 & 57.7 & 42.3 & 43.21 & 53.2 & 40.05 & 59.95 & 46.3 & 51.9 \\
\hline Volta & 93.2 & 3.6 & 94.5 & 4.7 & 59.1 & 40.9 & 86.81 & 6.64 & 88.47 & 11.53 & 83.8 & 14.2 \\
\hline Eastern & 57.3 & 37.7 & 53.8 & $45 . ' 0$ & 59.4 & 40.6 & 41.34 & 54.97 & 37.59 & 62.41 & 38.3 & 60.2 \\
\hline Ashante & 32.9 & 60.5 & 32.8 & 65.8 & 29.2 & 70.1 & 22.73 & 75.6 & 20.11 & 79.89 & 24.'0 & 74.6 \\
\hline B/Ahafo & 61.9 & 29.5 & 61.7 & $36 . ' 0$ & 58.1 & 41.9 & 44.64 & 50.6 & 41.7 & 58.30 & $46 . ' 0$ & 51.9 \\
\hline Northern & 63.'0 & 16.3 & 62.1 & $32 . ' 0$ & 88.8 & 11.2 & 50.75 & 29.6 & 51.1 & 48.90 & 56.9 & 36.2 \\
\hline U/west & $51 .{ }^{\prime} 0$ & 8.9 & 74.6 & 11.2 & 95.7 & 4.3 & 62.29 & 15.5 & 57.17 & 42.83 & 56.6 & 32.2 \\
\hline U/East & $54 . .^{\prime} 0$ & 10.5 & 69.'0 & 17.4 & 62.5 & 37.5 & 52.07 & 21.5 & 61.97 & 38.03 & 53.9 & 31.6 \\
\hline Total & 58.4 & 30.3 & 57.4 & 39.6 & & & 44.85 & 48.4 & 43.1 & 56.90 & 44.6 & 52.4 \\
\hline
\end{tabular}

Source: Sources: culled from Krutz 2005, Ayee 1998: 43; 1998 Afrobarometer; Electoral Commission of Ghana 2001: 27 Electoral mission, 2005, <<http://www.ghanaweb.com/GhanaHomePage/election2004/election.results.php\#region1〉>

\section{APPENDIX 3}

Source: Culled from Krutz 2005

\begin{tabular}{|lcccccccccc|}
\hline \multicolumn{1}{|c}{ REGION } & $\mathbf{A}$ & $\mathbf{B}$ & $\mathbf{C}$ & $\mathbf{D}$ & $\mathbf{E}$ & $\mathbf{F}$ & $\mathbf{G}$ & $\mathbf{H}$ \\
\hline Greater Accra & $\phi 11,613,955$ & 180,642 & $\phi 64,292.11$ & $\phi 339,700$ & $2,903,753$ & $\phi 116.99$ & $\phi 586098$ & $\phi 201.84$ & $\phi 32,927$ & $\phi 11,339$ \\
Volta & 20036495 & 215496 & 92978.5 & 1055200 & 1630254 & 647.26 & 175907 & 107.9 & 2044 & 1253.79 \\
Eastern & 25948202 & 272422 & 95250.02 & 920100 & 2101650 & 437.8 & 278459 & 132.5 & 1135.5 & 540.29 \\
Central & 14897586 & 190751 & 78099.65 & 1205100 & 1593888 & 756.08 & 212444 & 133.2 & 500 & 313.7 \\
Western & 15655738 & 195229 & 80191.66 & 553600 & 1916748 & 288.82 & 194975 & 101.72 & 5640 & 294.25 \\
Ashante & 34838294 & 333940 & 104325.01 & 971400 & 3600358 & 269.81 & 228336 & 634.2 & 7135.5 & 1981.89 \\
Brong Ahafo & 18464778 & 198825 & 92869.5 & 396200 & 1798058 & 220.35 & 165032 & 4.5 & 19220 & 1068.93 \\
Northern & 10121812 & 136328 & 74246.02 & 421200 & 1805428 & 233.3 & 186183 & 91.78 & 23529 & 13032.4 \\
Upper East & 4627666 & 75758 & 61084.85 & 241300 & 919549 & 262.41 & 142917 & 155.42 & 21997 & 23921.5 \\
Upper West & 3564350 & 48909 & 72877.18 & 226100 & 575579 & 392.82 & 86204 & 149.77 & 0 & 0 \\
\hline TOTAL & 159768896 & 1858300 & 86441 & 6329900 & 18845265 & 335.89 & 225655 & 119.74 & 114128 & 6056.06 \\
\hline
\end{tabular}

A. Ghana Education Service (Primary Education) (1997 estimates) (in thousands of cedis)

B. Primary school enrollment (1992/3) (source: Ministry of Education)

C. Average spending per pupil

D. Ministry of Education, Development spending (1996 actual) (in thousands of cedis)

E. Regional population (source: 2000 Ghana Census)

F. Per capita education development spending

G. Ministry of Works and Housing (1997 estimates) (in thousands of cedis)

H. Per capita MoWaH spending

I. $\quad$ Min of Roads \& Highways, Development spending (1997 ests.) (in hundreds of thousands of cedis)

J. Per capita MoRaH development spending

Unless noted, all data from Ghana National Budget Estimates (1997)

34 With minor parties and non-partisans excluded.

35 Results are for the first round elections of 7 December. 


\section{REFERENCES}

1. Afrobarometer (2002). Key Findings about Public Opinion in Africa (Briefing Paper 1).

2. Ayee, Joseph R. A. (1998). The 1996 General Elections: An Overview, in Joseph R. A. Ayee, ed., The 1996 General Elections and Democratic Consolidation in Ghana (Accra: Gold-Type Ltd.), pp. 35-52.

3. Ayee, Joseph R. A. (2005). Voting Pattern in the 2004 Elections, in Electoral Commission of Ghana and Joseph R. A. Ayee, ed., Elections 2004 - Ghana's Parlimentary and Presidential Elections (Accra: O'mens graphics.), pp. 82-93.

4. Baines, P. R. and Egan, J. (2001) Marketing and Political Campaigning: Mutually Exclusive or Exclusively Mutual?, Qualitative Market Research: An International Journal, Vol. 4, N.1, pp. 25-33.

5. Bawumia, Mahamudu (1998). Understanding the Rural-Urban Voting Patterns in the 1992 Ghanaian Presidential Elections: A Closer Look at the Distributional Impact of Ghana's Structural Adjustment Programme, Journal of Modern African Studies, vol. 36, no. 1, pp. 47-70.

6. Butler, P. and Collins, N. (1996), Strategic Analysis in Political Markets, European Journal of Marketing, Vol. 30 No. 10/11, pp.32-44.

7. Chazan, Naomi. (1981) The State, ethnicity and politics in Ghana. Paper presented at African 24th Meeting of Studies Association, Bloomington, Indiana.

8. Chazan, Naomi (1982a). Ethnicity and Politics in Ghana. Political Science Quarterly, 97(3). St. Martin's Press.

9. Chazan, Naomi (1983). An Anatomy of Ghanaian Politics: Managing Political Recession 1969-1982.

Boulder: Westview.

10. Cohen, Abner, 1993. Introduction: The lesson of ethnicity, p.136-138 in Ernfors, Rúnar Fr. (ed) Ethnicity and Democracy: An Annotated Bibliography with a Focus on Africa. Stockholm University: Stockholm.

11. Cohen, Denis L. (1983). Elections and Election Studies in Africa, in Yolamu Barongo, Political Science in Africa: A Critical Review (London: Zed Press), pp. 72-93.

12. Dovlo, Elom. (2003) Christian Missions and Nation Building in Ghana: An Historical Evaluation. in Uniquely African? : African Christian identity from cultural and historical perspectives, edited by James L. Cox and Gerrie ter Haar. Trenton, Nj: Africa World Press.

13. Freedom House (2005). Freedom in the World Country Rankings. Online. http://www.freedomhouse.org/ratings/index.htm. Available (25 February 2005).

14. Ghana Information Services Department (GISD), (1994) GHANA - a brief guide 1994 Ghanaweb. Culled from the booklet Ghanaweb.

15. Ghana Web, (1994-2006), Early European Contact and the Slave Trade, Ghana Home Page. http://www.ghanaweb.com/GhanaHomePage/history/slave-trade.php.

16. Hauer M, (2004). The Ethnic Knife - A Minor Field Study of Organizations Based on Ethnicity in Ghana, Department of Political Science, Lund University.

17. Hayes, B. and McAllister, I. (1996), Marketing Politics to Voters: Late Deciders in the 1992, British Election, European Journal of Marketing, Vol. 30 No. 10/11, pp.135-146.

18. Henneberg, S. C. (2003) Generic Functions of Political Marketing Management, Working Paper 2003.19, School of Management, University of Bath.

19. Henneberg S. C. M, (2004), Political Marketing Theory: Hendiadyoin or Oxymoron University of Bath, School of Management, Working Paper Series.

20. Jonah, Kwesi (1998). Agency and Structure in Ghana's 1992 and 1996 Presidential Election, in Joseph R. Ayee, ed., The 1996 General Elections and Democratic Consolidation in Ghana (Accra: Gold-Type Ltd.), pp. 229-57.

21. Kavanagh, D. (1995) Election Campaigning: The New Marketing of Politics Blackwell, Oxford.

22. Kotler, P. (1972) A Generic Concept of Marketing, Journal of Marketing, Vol. 36, April, pp. 46-54 John G., Nyuot Yoh, Department of Political Sciences, University of South Africa (UNISA) John R. Lott Jr. ${ }^{1}$ and W. Robert Reed ${ }^{2}$ United States Sentencing Commission, 1331 Pennsylvania Ave. N.W., Suite 1400, 20004 Washington, DC, Department of Economics, Texas A\&M University, 77843 College Station, TX

23. Kotler, P. and Kotler, N. (1999) Political Marketing, in B. I. Newman (Ed.), Handbook of Political Marketing, Sage, Thousand Oaks, pp. 3-18. 
24. Krutz j., (2005) Determinants of Party Support in Ghana's Fourth Republic Shirking and sorting in a political market with finite-lived politicians Columbia University Hankamer School of Business, Baylor University, Waco, Texas, 76798-8003, USA.

25. Lees-Marshment, J. (2001) Political Marketing as Party Management - Thatcher in 1979 and Blair in 1997 , Department of Politics, Keele University, National Europe Centre Paper No.110.

26. Lees-Marshment, J. (2003) Political Marketing: How to Reach That Pot of Gold, Journal of Political Marketing, Vol. 2, N. 1, pp. 1-32.

27. Lees-Marshment, J. (2001) Political Marketing and British Political Parties, Manchester University Press, Manchester.

28. Lock, A. and Harris, P. (1996) Political Marketing - Vive La Difference!, European Journal of Marketing, Vol. 30 No. 10/11, pp.21-31.

29. Marland, A., (2003) Political Marketing in modern Canadian Federal Elections .Department of Politics \& International Relations Lancaster University Paper for presentation at the Canadian Political Science Association Conference 2003, Dalhousie University.

30. Newman, Bruce I. 1994. The Marketing of the President: Political Marketing as Campaign Strategy. Sage.

31. Newman, B. I. (1995) Political Marketing as a Governing Tool, Werbeforschung \& Praxis, Vol. 5, pp. 163167.

32. Niffenegger, P.B. 1989. Strategies for Success from the Political Sage Publications, London.

33. O'Leary, R. and Iredale, I. (1976), The Marketing Concept: Quo Vadis?, European Journal of Marketing, Vol. 10 No. 3, pp. 146-157.

34. O'Shaughnessy, N. J. (1990) The Phenomenon of Political Marketing, Macmillan, Basingstoke.

35. O'Shaughnessy, N. J. (2002) The Marketing of Political Marketing in N. O'Shaughnessy and S. C. Henneberg (Eds.), The Idea of Political Marketing, Praeger, Westport, pp. 209-220.

36. O'Shaughnessy, N. J. (2003) The Symbolic State: A British Experience, Paper presented at the 2003 Political Marketing Conference, London, Sept.

37. O'Shaughnessy, N. J. and Henneberg, S. C. (2002a) Introduction in N.O'Shaughnessy and S. C. Henneberg (Eds.), The Idea of Political Marketing, Praeger, Westport, pp. xi-xx.

38. Rothchild, D. (1978) Ethnicity and Purposive Depoliticalization: the Public Policies and Two Ghanaian Military Regimes, paper presented at the twenty -First Annual Meeting of African Studies Association, November 1978.

39. Rothchild, Donald (1995). Rawlings and the Engineering of Legitimacy in Ghana. In: Zartman, I. William. Collapsed States The Disintegration of Legitimate Authority. Boulder: Lynne Rienner.

40. Scammell, Margaret. 1994. The Phenomenon of Political Marketing: The Thatcher Contribution. Contemporary Record 8(1): 23-43 (Summer).

41. Scammell, M. (1995) Designer Politics, Macmillan, Basingstoke.

42. Shama, A. (1975), The Marketing of Political Candidates, Journal of the Academy of Marketing Science, Vol. 4 No. 4, pp. 767-777.

43. Smith, G. and Saunders, J. (1990) The Application of Marketing to British Politics, Journal of Marketing Management, Vol. 5, N. 3, pp. 307-323.

44. Van de Walle, Nicolas (2003). Presidentialism and Clientelism in Africa's Emerging Party Systems, Journal of Modern African Studies, vol. 41, no. 2, pp. 297-321. Wantchekon, Leonard (2003).

45. Wring, D. (1997), Reconciling Marketing with Political Science: Theories of Political Marketing, Proceedings from the Academy of Marketing Conference, Manchester Metropolitan University, Manchester.

46. Yalea, Papa, Tension in Ghana: the Solution is In a feature article, Ghana Web, (06:01:2006).

47. Yorke, D. A. and Meehan, S. A. (1986), ACORN in the Political Marketplace, European, Journal of Marketing, Vol. 20 No. 8, pp.63-76. 